JURNAI AL BAYAN: JURNAL JURUSAN PENDIDIKAN BAHASA ARAB

\title{
Improving Students' Professionalism in Arranging and Developing RPP through Curriculum Development and Learning Planning Courses
}

\author{
Umi Hanifah \\ Pendidikan Bahasa Arab Universitas Islam Negeri Sunan Ampel Surabaya, Indonesia
}

Article History:

Received : March 26 $6^{\text {th }}, 2019$

Revised : April 19th 2019

Accepted : May $20^{\text {th }}, 2019$

Published : June $1^{\text {st }}, 2019$

\section{Keywords:}

Curriculum; Learning; Planning;

Profesionalism

*Correspondence Address:

umihanifah@uinsby.ac.id

\begin{abstract}
The aim of this study was to find out the improvement in the ability of PBA students in arranging and developing RPP and their problems through Curriculum and Learning Planning Development courses in PBA Program Study of Sunan Ampel Surabaya University. The results showed that the lectures with portfolio-based learning models could improve the professionalism of PBA students in arranging and developing RPP. The increase was indicated by the results of the RPP assessment conducted by comparing the increase in scores between before and after the RPP was presented, criticized and assessed using the RPP assessment instrument. Before being presented and corrected the result (33.3\%) and after the results became (73.3\%). The level of problems in compiling and developing RPP is low. Then for the maximal result, it hopes that the portfolio learning model should be variated with the study lesson model in each meeting, especially in arranging lesson plan.
\end{abstract}

\section{Introduction}

The teacher as an educational agent in the school is required to be able to carry out the quality of learning. Therefore, the teacher should be professional and qualified. Because the professional and qualified teacher will be able to create a qualified youth generation. According to the Peraturan Menteri Pendidikan Nasional Republik Indonesia Number 162007 about the Standard of Academic Qualification and the Teacher's Competence, it mentions that the teacher's competence includes the pedagogic, personality, social, and professional competence. ${ }^{1}$ Thus, professional and qualified teachers are directly proportional to the weight of their competence.

One of the professional teachers' indicator is they are who can make a lesson plan

1 Badan Standar Nasional Pendidikan, Peraturan Menteri Pendidikan Nasional Republik Indonesia Nomor 16 Tahun 2007 Tentang: "Standard Kualifikasi Akademik Dan Kompetensi Guru" (Jakarta: Sekretariat Negara, 2007). Periksa juga Faizuz Sa'bani, "Peningkatan Kompetensi Guru dalam Menyusun RPP melalui Kegiatan Pelatihan pada MTs Muhammadiyah Wonosari", dalam Jurnal Pendidikan Madrasah, Volume 2, Nomor 1, Mei 2017. 13-22. 
well. As the Permendiknas Number 162007 above, the pedagogic competence related to the teacher' ability in planning, implementing and evaluating the learning process. While the success of implementing and evaluating the learning process is determined by the teacher' ability in planning the learning process.

Arranging the lesson plan is a must for the teacher. Because of it a tool for control and as the guideline in implementing the learning process. The succeed of the process and outcome from the learning are determined by the quality of the lesson plan arrangement. Hence, the teacher must have competence in arranging a good lesson plan. A good lesson plan who made by the teacher must appropriate with the guideline, which is Permendikbud Number 22 2016. ${ }^{2}$ Besides that, the good lesson plan is the lesson plan which appropriates with the students' characteristics and the condition of the school where the teacher thaught.

One of the serious problems faced in the educational world today is the low of learning quality. The learning occurs often not based on good planning. The learning only makeshift, routine, formality, less of meaning, the quality of such learning will give a low quality of learning result. ${ }^{3}$ The low quality of learning is caused by the low of the teacher' professionalism in planning and implementing the learning. So that, to improve the quality of learning, various efforts have been made by the government or private parties, such as workshop, training, technical guidance and teacher competency test. However, it has not been able to show a significant increase in teacher professionalism.

Improving the quality of learning should begin by a good learning design, in other words, the learning planning can be used as a starting point of effort in improving the quality of learning. Because the existence of the learning planning will make the learning process more directed so that it can deliver the students to target the education goal. ${ }^{4}$ It supported by the result of the Chair' research cited in Muhaimin; the learning activity which is begun by doing the arrangement of lesson plan will improve the quality of the learning and the outcome. Thus, the first step in improving the quality of learning is through professional learning planning. ${ }^{5}$

Therefore, since in college a candidate teacher must have the basics of competence which is got from the lecture activity. Essentially, teaching is not only

\footnotetext{
2 Mendikbud, "Permendikbud No. 22 Tahun 2016 Tentang Standard Proses" (Jakarta, 2016).

${ }^{3}$ Muhaimin, Paradigma Pendidikan Islam (Bandung: Remaja Rosda Karya, 2004), page. 190.

${ }^{4}$ Hamzah B. Uno, Perencanaan Pembelajaran, (Jakarta: PT. Bumi Aksara, 2016), page. 2-6.

${ }^{5}$ Muhaimin, Paradigma Pendidikan Islam, page. 190.
} 
delivered information but also about perseverance, patience, affection, and dedication. The professional teacher is needed because the teacher is one of the determinants of learning success.

In some research results, it was found that there were many teachers who were less professional in preparing lesson plans, so in this study, the author tried to examine how a prospective teacher practiced compiling and developing lesson plans well since they were still studying in college, so that after becoming teachers, they will be a skilled and professional teacher in compiling and developing lesson plans.

As one of the teacher education institution in university level, LPTK Fakultas Tarbiyah dan Keguruan (FTK) UIN Sunan Ampel has the main function in order to prepare the candidate teachers who will be able to implement their duties as the professional in elemantary, junior and high school level. The Program Studi Pendidikan Bahasa Arab (PBA) in Fakultas Tarbiyah dan Keguruan (FTK) UIN Sunan Ampel is a study program in the education field. One of the subjects that must be taken by UIN Sunan Ampel students, especially in the field of education, is Curriculum Development and Learning Planning. ${ }^{6}$

The purpose of lecturing the Curriculum Development and Learning Planning in the Pendidikan Bahasa Arab (PBA) program study at the Fakultas Tarbiyah dan Keguruan (FTK) UIN Sunan Ampel is to train the Arabic candidate teacher how to developing curriculum, arranging and developing the learning planning through training and practicing stages which are guided and integrated in order to form the professional teacher. ${ }^{7}$

The candidate of Arabic teachers' competence in arranging the learning planning can be seen when the implementation of Praktik Pengalaman Lapangan (PPL) runs, either PPL 1 or PPL 2. Praktik Pengalaman Lapangan (PPL) in di Fakultas Tarbiyah dan Keguruan (FTK) UIN Sunan Ampel Surabaya is one of the activity sequences for applying various educational theory through teaching practice or educational task outside teaching are guided and integrated in order to form professional teacher. ${ }^{8}$ The implementation of the PPL lesson refers to Undang-Undang Guru dan Dosen number 14

${ }^{6}$ Prodi PBA FTK UINSA, "Struktur Kurikulum Pendidikan Bahasa Arab Fakutas Tarbiyah Dan Keguruan UIN Sunan Ampel Berbasis KKNI." (FTK UINSA, 2016).

7 Team Dosen PBA, "Syllabus Mata Kuliah Pengembangan Kurikulum Dan Perencanaan Pembelajaran Program Studi PBA Pada FTK UIN Sunan Ampel Surabaya" (Prodi PBA UINSA, 2018).

${ }^{8}$ Fakultas Tarbiyah dan Keguruan UIN Sunan Ampel, Pedoman Praktek Pengalaman Lapangan (PPL I) Tahun 2017 (Sidoarjo: Dwi Putra Pustaka Jaya, 2017), page. 1. 
2005, specifically those relating to four teacher competence, such as: pedagogic, personality, professionality, and social competence. ${ }^{9}$

The researcher is one of the PPL 1 lecturer in Pendidikan Bahasa Arab (PBA)program study at Fakultas Tarbiyah dan Keguruan (FTK) Islamic University of Sunan Ampel Surabaya, based on the researcher's experience, in implementing PPL 1 the whole students of Pendidikan Bahasa Arab (PBA) study program at the Tarbiyah and Teacher Training Faculty of Islamic University of Sunan Ampel Surabaya experiencing various problem, of which they have not been skilled in preparing learning planning. Thus, the problem faced by college students is when the lecturer gives a task to the students for arranging RPP (Rencana Pelaksanaan Pembelajaran) before they practice to teach. Moreover even in the 2015/2016 academic year, the candidate of the Arabic teacher in Pendidikan Bahasa Arab study program of Fakultas Tarbiyah dan Keguruan UIN Sunan Ampel Surabaya have not got the Learning Planning study program, until they follow the PPL 1 lesson so they asked by the PPL 1's lecturer to practice arranging RPP before they practice to teach. ${ }^{10}$ Consequently, PPL 1's lecturer is required to give the material about the theory of arranging the learning planning in several meetings before starting the microteaching activity in PPL 1 . Whereas in the PPl 1 activity, the students should no longer have the lesson plan material but directly practice to arrange the lesson plan which is appropriate with the time allocation and basic competence determined by the lecturer before the teaching practice.

Starting in the odd semester 2017/2018 the writer is involved as the lecturer in the Curriculum Development and Learning Planning lesson courses. As a lecturer in Curriculum and Learning Planning Development Courses, the writer is interested in reviewing the Prospective Arabic Language Teachers in Arranging and Developing RPP. Through Curriculum Development and Learning Planning in PBA study program of FTK UIN Sunan Ampel, with the aim of increasing the professionalism Arabic teacher candidates in developing curriculum and learning tool while improving the quality of learning, especially in Pendidikan Bahasa Arab (PBA) study program of Fakultas Tarbiyah dan Keguruan (FTK) UIN Sunan Ampel Surabaya and generally in Indonesia.

9 Departemen Agama RI, Undang-Undang Dan Peraturan Pemerintah RI Tentang Pendidikan (Jakarta: Depag, 2007), 248 pages.

${ }^{10}$ Hasil investigasi Team Dosen PPL 1 PBA UINSA, bahwa "Tidak diberikannya Mata Kuliah Perencanaan Pembelajaran (I'dad al-Ta'lim) adalah karena terlewatkan (kealpaan) pihak Prodi. Pada akhirnya sebagai solusi dimasukkan ke dalam Mata Kuliah PPL 1 (include) pada semester tersebut". (n.d.). 
The problems which are focused in this research are: How is the process of learning Curriculum Development and Learning Planning in Pendidikan Bahasa Arab (PBA) study program Fakultas Tarbiyah dan Keguruan FTK Universitas Islam Negeri Sunan Ampel Surabaya can improve the professionalism of the prospective Arabic teacher in arranging and developing the learning planning? And what are the problems faced by the prospective Arabic teacher in the Pendidikan Bahasa Arab (PBA) study program of Fakultas Tarbiyah dan Keguruan (FTK) Universitas Islam Negeri Sunan Ampel Surabaya in arranging and developing the learning planning and what are the solution?

\section{Theoretical Support}

\section{An overview of Curriculum Development and Learning Planning Courses.}

The competence which is expected from the implementation of the curriculum development and learning planning courses is a student who understands the basis of curriculum development through the development of learning tool, Arabic learning planning and the implementation, the steps, the models, and the design of Arabic learning planning. The Curriculum and Learning Planning Development Courses is basic training for the students before they implement the teaching practice activity (PPL-1). ${ }^{11}$ This course presents how good planning and all the components related to the Arabic teaching-learning activity will be carried out. These components include the goal planning, material, method, media/ tool/learning source, assessment tool and others which are included in the learning system or sub-system.

As the framework of Indonesia national qualification, Curriculum and Learning Planning Development Course is a compulsory course in Pendidikan Bahasa Arab (PBA) study program of FTK UIN Sunan Ampel with 3 credits. In 2018, Learning Planning, thus the course' name become Learning Planning and Curriculum Development.

The learning outcomes from this course are able to develop the Arabic Language Curriculum in school/ madrasah in accordance with the procedures and principles in curriculum development, able to arranging the Arabic learning tool in school/madrasah, solving the apparent problem and adapt to the situation which is faced by utilizing the

11 Team Dosen PBA, "Silabus Mata Kuliah Pengembangan Kurikulum Dan Perencanaan Pembelajaran Program Studi PBA Pada FTK UIN Sunan Ampel Surabaya, 2018." 
development of the latest IPTEKS, able to carry out the Arabic learning in the class and able to evaluate the Arabic learning school/madrasah. ${ }^{12}$

Learning Planning and Curriculum Development courses are delivered in the fifth semester. This course is one of the required courses for the Praktik Pengalaman Lapangan (PPL-1) course in Fakultas Tarbiyah dan Keguruan UIN Sunan Ampel. If the student doesn't pass this course, he can not program the PPL-1 in the next semester automatically.

It has become a necessity of the current era that Arabic teacher should be able to more active, not only as the wisdom operator but also as the creator and innovator, especially in managing and making policy in the class, for example developing syllabus in Arabic study program moreover in making and developing the RPP.

\section{Teacher Professionalism}

Before discussing the definition of professionalism, it better to discuss the definition of the profession which is the basic word of professionalism, thus the writer will be easier in giving the professionalism definition. In a contemporary language dictionary, the word profession is defined as a filed of job which is based on certain skill education. $^{13}$

Meanwhile, in English is "profession" which means position, job, livelihood, or who has expertise. ${ }^{14}$ Whereas, according to Hamalik, the profession is a statement that a person will devote himself to a position or job because he called to take the job. ${ }^{15}$ Thus, literally, the word profession means a job which requires skill and certain creativity, where the skill and creativity are got from special education or training.

Furthermore, according to Uzer Utsman, the word professional is derived from the adjective which means livelihood and as a noun which means a person who has

12 Prodi PBA FTK UINSA, "Struktur Kurikulum Pendidikan Bahasa Arab Fakutas Tarbiyah Dan Keguruan UIN Sunan Ampel Berbasis KKNI."

13 Yenny Salim, Kamus Indonesia Kontemporer, Modern English (Jakarta: Modern English Press, 1991), page. 92.

14 William Keheli dan Michael Andreas, Kamus Lengkap Praktis Bahasa Inggris Indonesia (Surabaya: FajarMulia, 1999), page. 144. Periksa juga WJS. Poerwadarminto, Kamus Bahasa Inggris Indonesia (Bandung: Hasta, 1982), page. 162.

${ }^{15}$ Oemar Hamalik, Pendidikan Guru Konsep Atau Strategi (Bandung: Mandar Maju, 1991), page. 1. 
expertise such as a teacher, doctor, judge, and others. ${ }^{16}$ Whereas professionalism is the ownership of a set of skills or expertise in a certain legalized field and certified by an institution. A professional has the right to get a reasonable reward that becomes the main supporter in pioneering his career in the future. ${ }^{17}$

In line with the description above, professionalism comes from the word profession, while the profession itself means a job which requires a skill that got from education or special training. Thus according to Arifin, the definition of professionalism is "a view which is a particular skill needed in a certain job where it got from the special education and training". ${ }^{18}$ While Ahmad Tafsir states, professionalism is an understanding which teaches that each job should be done by the professional person. ${ }^{19}$

Based on the descriptions above, it can be concluded that teacher professionalism is an action of attitude which has by the teacher in supporting his job that based on the understanding that teaches in doing a profession should be based on the professional competence which includes knowledge, expertise, and creativity that support he is engaged in. Professionalism means a nature that should be possessed by every professional in carrying out his job, thus it job can be done well, full of response to what has been done based on his education and creativity. Furthermore," teacher professionalism" is a nature that must exist in a teacher in carrying out her work in order to make the teacher responsible and can develop her skill without interfering her main duty. In the other hand, the professional understanding in Islam, especially in the field of education, that a person must truly have an adequate scientific educational quality to support the duties of his profession and not everyone can do a good job. if the assignment is delegated to someone who is not expert then it will not succeed and even will fail, as the Prophet Muhammad said:

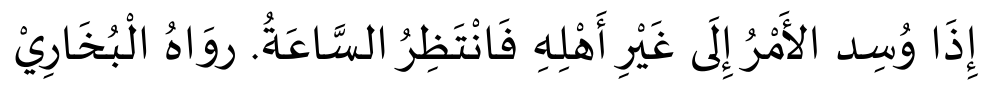
page. 8.

${ }^{16}$ Mochammad Uzer Utsman, Menjadi Guru Profesional (Bandung: Remaja Rosda Karya, 1995),

17 Ibrahim Bafadal, Peningkatan Profesional Guru Sekolah Dasar, (Jakarta: Bumi Aksara, 2003), page. 20.

${ }^{18}$ H.M. Arifin, Kapita Selekta Pendidikan (Jakarta: Bumi Aksara, 1991), page. 105.

${ }^{19}$ Ahmad Tafsir, Ilmu Pendidikan Dalam Perspektif Islam (Bandung: Remaja Rosda Karya, 1994), page. 107. 
Meaning:" If a case is submitted to someone who is not expert, the wait for its destruction". (Narrated by Bukhari)

The Word of Allah SWT QS. al-Isra' verse 84:

Meaning: Say: "Each person behaves according to his own circumstances".

\section{Arabic Education's Students}

The students' of Pendidikan Bahasa Arab (PBA) study program is the students who take the Arabic Education study program. In the Arabic Education study program, the students are studying education and Arabic learning. The students who program the Curriculum and Learning Planning are the students on the fifth semester who will follow the PPL1 course in the sixth semester.

Pendidikan Bahasa Arab (PBA) study program of Fakultas Tarbiyah dan Keguruan (FTK) UIN Sunan Ampel has a vision as a center for the study which is excellent, qualified, competitive and becomes a recommended program study to the International Arabic Education". ${ }^{20}$

The objectives of Pendidikan Bahasa Arab (PBA) study program of Fakultas Tarbiyah dan Keguruan (FTK) UIN Sunan Ampel are:

a. Produce an Arabic Education Bachelor who has religious knowledge and attitude.

b. Produce an Arabic Education bachelors who are professional in doing their assignment.

c. Produce an Arabic Education Bachelor who able to respond to the development and community needs also able to do some new innovations in the Arabic Education' filed.

d. Produce an Arabic Education bachelors who able to give an example in life on the basis of Islamic values and culture noble of the nation.

While the target of Pendidikan Bahasa Arab (PBA) study program of Fakultas Tarbiyah dan Keguruan (FTK) UIN Sunan Ampel are: Arabic Education bachelors who has academic skill, professional and excellent in its field so that it is reflected as the profile of Arabic Education which professional, excellent and responsive in an effort to produce new innovations in scientific development in language education.

${ }^{20}$ Team Borang PBA FTK UINSA, “Borang Prodi PBA FTK UINSA 2016” (FTK UINSA, n.d.). 


\section{Previous Research}

In $2017,{ }^{21}$ the writer conducted a research about the innovation of learning and the assessment in finding the solution of the students' problem in VI semester of Pendidikan Bahasa Arab (PBA) study program of Fakultas Tarbiyah dan Keguruan UIN Sunan Ampel in 2016/2017academic year in Praktek Pengalaman Lapangan 1 (PPL I) program by the objective to improving the quality of the graduate students of Pendidikan Bahasa Arab (PBA) study program of Fakultas Tarbiyah dan Keguruan (FTK) UIN Sunan Ampel as the professional teacher candidates. Including their quality in applying the learning theories from the planning until the implementation and learning evaluation. Whereas in 2018 academic year (in this research), the writer conducted a research about the improvement of the professionalism of the students prospective Arabic teachers in arranging and developing rencana pelaksanaan pembelajaran (RPP) through Curriculum Development and Learning Planning course in Prodi Pendidikan Bahasa Arab (PBA) study program of Fakultas Tarbiyah dan Keguruan (FTK) Universitas Islam Negeri Sunan Ampel Surabaya as the analysis process of the leaning in Curriculum Development and Learning Planning course by the same objectives, that is improving the quality of the graduate students of Pendidikan Bahasa Arab (PBA) study program of Fakultas Tarbiyah dan Keguruan (FTK) Universitas Islam Negeri Sunan Ampel as the prospective teacher of Arabic who is professional.

Thus, this research focuses on the effort to improve the graduates quality of the Pendidikan Bahasa Arab (PBA) study program of Fakultas Tarbiyah dan Keguruan (FTK) Universitas Islam Negeri (UIN) Sunan Ampel in mastering the creativity to arrange lesson plan. So, it can be said that the 2018 research is the continuation of the writer's research in 2017.

\section{Method}

The writer used descriptive analytical research method. The descriptive method is the steps which are taken in the context of object represtation of reality that contains in the problem studied. Namely, a method which uses systematically to describe all things related to the problem. Furthermore, from the data collection which has processed and

${ }^{21}$ Umi Hanifah, "Laporan Penelitian 2017 "Inovasi Pembelajaran Pada PPL-1 Prodi PBA FTK UIN Sunan Ampel: Upaya Meningkatkan Profesionalisme Calon Guru" (Surabaya: LPPM - UIN Sunan Ampel, 2017). 
arranged by giving the explanation from its data, then it analyzed. ${ }^{22}$ Therefore, this method often called the descriptive-analytical method. In line with this research, descriptive- analytical method is mainly used to describe the objective condition about the implementation of curriculum development and learning planning lectures to the students of Pendidikan Bahasa Arab (PBA)study program of Fakultas Tarbiyah dan Keguruan UIN Sunan Ampel and also the obstacles which faced will analyze critically.

As for collecting the data, the writer used the observation method which was the observation and the systematic recording of the phenomena studied. ${ }^{23}$ This technique was used by the writer to get an explanation about the implementation of the curriculum development and learning planning course in Pendidikan Bahasa Arab (PBA) study program of Fakultas Tarbiyah dan Keguruan (FTK)Universitas Islam Negeri Sunan Ampel Surabaya and the related condition with this research. Then interview method and questionnaire were targeted to the lecturer who lectured the curriculum development and learning planning and the students on V Kelas A, B, dan C who take this course at Pendidikan Bahasa Arab (PBA) study program of Fakultas Tarbiyah dan Keguruan (FTK) UIN Sunan Ampel. The interview and questionnaire used to explore data about the process of the implementation of curriculum development and learning planning course and what are the problems which faced while taking this course especially in arranging and developing a lesson plan in Arabic Education study program of FTK UIN Sunan Ampel Surabaya and also the solution. Furthermore, the writer also used documentation method, namely the search for on things or variables in the form of notes, transcripts, inscriptions, books, letters, magazines, minutes, agendas, etc. The documentation required in this research was RPP by the fifth (V) semester students of Pendidikan Bahasa Arab (PBA) study program of Fakultas Tarbiyah dan Keguruan (FTK) UIN Sunan Ampel yang which has been corrected and assessed by the lecturer by using special assessment tool for lesson plan, textbook, lecture journals, attendance, grades and the documents which were contained the information related with the research.

While the data analysis for qualitative data in this study was done by using descriptive non statistic, that was data which was in form of numbers obtained from

${ }^{22}$ Hadhari Nawawi, Metode Penelitian Bidang Sosial (Yogyakarta: Gajah Mada University Press, 1995), page. 63. Periksa juga Winarno Surachmad, Dasar Dan Teknik Research (Bandung: Tarsito, 1978), page. 132.

${ }^{23}$ Sutrisno Hadi, Metodologi Research (Yogyakarta: Andi Offset, 1991), page. 136. 
observation, questionnaire, interview, and documentation conducted in inductive and deductive ways. ${ }^{24}$ Whereas deductive is a way to draw the conclusion that departs from general facts and start from general knowledge to something specific.

\section{Result and Discussion}

Increasing Students Professionalism in Arabic Education study program of FTK UIN Sunan Ampel in Arranging and Developing Lesson Plan through Innovation in Portfolio-Based Learning in Curriculum Development and Learning Planning Course

The learning process of the Curriculum Development and Learning Planning Course in Pendidikan Bahasa Arab (PBA) study program of Fakultas Tarbiyah dan Keguruan (FTK) UIN Sunan Ampel for 2017/2018 and 2018/2019 academic year was better than previous years. It is seen from the steps of the learning in each meeting, from the $1^{\text {st }}$ meeting until the $16^{\text {th }}$ meeting is in accordance with the characteristic of the practice-based course. In Curriculum Development and Learning Planning Course, the students of prospective Arabic teacher are required to understand the theory and practice of curriculum development, arrangement, and development of syllabus and lesson plan.

The model of Curriculum Development and Learning Planning Course in Pendidikan Bahasa Arab (PBA) study program of Fakultas Tarbiyah dan Keguruan (FTK) UIN Sunan Ampel can be seen from the model, strategy and lecturing activity in each semester on one semester (16 meetings)bellow. ${ }^{25}$

The implementation of the model, strategy, and descriptions of learning activities in Curriculum Development and Learning Planning can be seen in the following explanation:

Meeting 1: Introduction/intro to subject. Intro to the subject activity will deliver to the lectures' introductory activity, the rules of class, according to the syllabus and RPS including the whole material which will be studied, how the activities are carried out in one semester, how the assignments and the assessment.

Meeting 2, 3, 4, dan 5: A deep discussion about curriculum and its development, What, Why and How the KTSP, What, Why and How the revision of 2013 curriculum,

\footnotetext{
${ }^{24}$ Sutrisno Hadi, Metodologi Research (Jakarta: Andi Offset, 1998), page. 3.

25 Team Dosen PBA, "Silabus Mata Kuliah Pengembangan Kurikulum Dan Perencanaan Pembelajaran Program Studi PBA Pada FTK UIN Sunan Ampel Surabaya."
} 
the basic difference of KTSP and 2013 curriculum.

Meeting 6: Discussion and Workshop about arranging Syllabus of the 2013 curriculum. Discussion and give an example of Arabic syllabus based on the revision of K'13 in the group, practice to arrange syllabus independently, collect portfolio independently in form of 2013 curriculum syllabus revised edition for MTS/SMP and MA/SMA levels.

Meeting 7: Discussion and Workshop of making RPE, Prota, Promes. This activity is an activity in equipping the students with skill/ competence in arranging RPE, Prota, and Promes. This activity (already) begins by giving an independent assignment to carry an educational calendar, learn and also carry an example of RPE, Prota, and Promes from the Arabic teacher. At the end of the meeting the students collecting the portfolio in form of RPE, Prota, Promes.

Meeting 8: UTS writing. The question about the material pre-UTS and analyzing the implementation of 2013 curriculum (the problem and solution) in school/madrasah as the partner of LPTK FTK UIN Sunan Ampel, then report it by writing and oral.

Meeting 9, 10, 11, 12: Discussion and Workshop of arranging 2013 curriculum RPP 2017 revised edition. This activity begins by introducing RPP to the students, giving the example of Arabic RPP, the tutorial to arrange RPP then continuing with the practice activity in arranging RPP. At the end of meeting 12, the students are giving the assessment sheet that will be used as the RPP assessment tool/instrument in the next meeting (assessment activities between friends), the students are asked to learn it an instrument.

Meeting 13: Presentation and Reflection. This activity is a presentation of RPP results by students representatives in front of the class/ their friends who guided by the lecture. This activity is carried out simultaneously with the assessment between friends and reflection. When students present their own RPP, the other students given each other an of the result of his friend's RPP (exchanging RPP) by using RPP assessment which was shared in the previous meeting. This activity ended by reading the score result and the comment from students and lecturer, the lecturer asked the students for return the RPP and also the result of the score to each of students as the reference to revising the RPP based on the result of RPP tool/instrument sheet correction.

Meeting 14: Microteaching and Reflection. This activity is a practice activity or teaching simulation by practicing RPP which is made by the students in front of the class. 
The student who practiced/ simulated is called a practitioner, while some of the other students play the role as the students, 2 students as observers(observers of RPP assessment and learning implementation), and 1 student as the photographer who is recording/documenting the practice of the learning. In meeting-14 the activity contains microteaching by $60 \%$ assumption and reflection $40 \%$ assumption from the total of the time that provided in meeting-14.

Meeting 15: Revision and the finishing of the assignment (Syllabus, RPE, Prota, Promes, RPP). In this meeting the students are asked to finishing/revising the arranging Syllabus, RPE, Prota, Promes and 2013 curriculum RPP revised 2017. Assignment. Then they consulted their portfolio to their lecturer (final guidance) and packing the portfolio in MAP MAP (hardcopy) and CD (softcopy).

Meeting 16: Reflection for the whole course and collecting the portfolio (Reflection activity for whole learning activities start from the beginning until the end of the meetings and collecting the portfolio). This activity is done for getting feedback from the students to the learning process that ongoing and collecting the students' portfolio as the final assignment (UAS).

Learning innovation which has been applied in Curriculum Development and Learning Planning Course in Pendidikan Bahasa Arab (PBA) study program of Fakultas Tarbiyah dan Keguruan (FTK) UIN Sunan Ampel as the model of portfolio-based learning by using active strategy learning.

An effort in improving and developing the students' prospective teacher competence in arranging and developing Arabic lesson plan is by applying appropriate learning model. Several learning models that are appropriate to the learning planning material especially RPP is a portfolio-based learning model.

Arabic Leaning Planning Course is the course that learns about the technique to arrange the lesson plan. In the process of this planning course, the students are introduced how to arranging RPP technique well, start from analyzing the basic ability of the students, determining the time allocation of the learning activity, indicator of competency achievement, learning media, learning source, teaching materials, and making appropriate instrument to measure the learning objectives.

Students of prospective teacher competence in arranging a good lesson plan is the basic and the main for the students of the prospective teacher. Thus, it needs an effort to improve the students of prospective teacher competence in arranging lesson pan in order 
to make them able to practice the Arabic learning process in the school/madrasah well so the learning objectives will achieve optimally.

In the teaching process is needed guidance activity, skill practice, intellectual skill practice, psychomotor skill and motivating students to have innovative ability and creativity in arranging RPP. Therefore, the lecturer should have an ability in creating and implementing several models and learning strategy that appropriates with the learning material, including the use of various sources and media to ensure learning effectiveness. $^{26}$

A portfolio-based learning model in Curriculum Development and Learning Planning Course is the learning model which makes the students active. The learning process which is following by the students is not only theoretical but also directly practice about how the technique of arranging and developing RPP in form of portfolio assignment. By practicing the way how to arrange this lesson plan, it hopes that the students' professionalism will improve.

In delivering the lesson plan material (RPE, Prota, Promes, Silabus dan RPP) the lecturer use workshop method, in the end of the lecturing process should be end by the assignment to arrange lesson plan, such as RPE, Prota, Promes, Syllabus and RPP for presenting and correcting then putting it into portfolio collection.

Especially for lesson plan material, it will emphasise more in it, besides it presented in form of its lesson plan and it corrected together by using assessment instrument especially lesson plan, and it also practice in form of peer teaching as the effort to harmonize between what is wroten in lesson plan with the implementation in the class, because what is written in lesson plan should be appropriate with the implementation.

It can be said that by innovating the portfolio-based learning in Curriculum Development and Learning Planning Course the students of Arabic in Pendidikan Bahasa Arab (PBA) program study of Fakultas Tarbiyah dan Keguruan (FTK) UIN Sunan Ampel in arranging and developing lesson plan can be increased.

${ }^{26}$ Endang Mastuti Rahayu, "Meningkatkan Kemampuan Menyusun Perangkat Pembelajaran Dalam Mata Kuliah Perencanaan Melalui Model Kotipare Pada Mahasiswa Semester V Mahasiswa Jurusan Pendidikan Bahasa Inggris FKIP-UNIPA Surabaya," Jurnal Buana Bastra Tahun I No. 1, (April 2004): 86. Periksa juga Norma Izzati, "Meningkatkan Kemampuan Mahasiswa Dakam Menyusun RPP Melalui Penerapan Model Pembelajaran Berbasis Portofolio"," Jurnal Euclid, 4 No. 1 (2017): 659. 
To see how the improvement of professionalism of the students' prospective Arabic teacher in arranging and developing lesson plans well, it used documentation analysis with the instrument of RPP assessment. The result of the RPP document created by students of Pendidikan Bahasa Arab (PBA) study program of Fakultas Tarbiyah dan Keguruan (FTK) UIN Sunan Ampel can be seen before the lesson plan presentation, peer assessment and intense guidance from the lecturer and afterward.

The result of the RPP document created by students of Pendidikan Bahasa Arab (PBA) study program of Fakultas Tarbiyah dan Keguruan (FTK) UIN Sunan Ampel can be seen before the lesson plan presentation, peer assessment and intensive guidance from the lecturer is seen on 2.1.

Table 1. The Result of RPP Assesment of 2013 Curriculum 2017 Revised Edition, beginning step before the RPP presentation, peer assessment, and advisor.

\begin{tabular}{|c|c|c|l|c|c|}
\hline NO & Score & Predicate & \multicolumn{1}{|c|}{ Explanation } & Total & \% \\
\hline 1 & N $<70$ & A & Need guidance & 8 & 26.6 \\
\hline 2 & $\begin{array}{c}71 \leq \mathrm{N} \\
\leq 80\end{array}$ & $\mathrm{~B}$ & $\begin{array}{l}\text { Can be used as the sample for } \\
\text { other prospective } \\
\text { students/teachers by revising } \\
\text { in certain parts. }\end{array}$ & 12 & 40 \\
\hline 3 & $\mathrm{~N}>80$ & $\mathrm{C}$ & $\begin{array}{l}\text { Can be used as the sample for } \\
\text { other prospective } \\
\text { students/teacher }\end{array}$ & 10 & 33,3 \\
\hline & & Total & 30 & 100 \\
\hline
\end{tabular}

The finding in table 2.1 show that the small portion (26.6\%) the students need guidance in arranging and developing lesson plan, while almost most of the students (40\%), their lesson plan can be used as the reference or example for the other students but it needs revision in certain part and almost half of the students $(33,3 \%)$ their lesson plan is recommended to be used for others students as the reference or example. From the finding, it can conclude that generally, the lesson plan which created by the students of Arabic prospective teacher in PBA FTK UIN Sunan Ampel can be references or example to other students/ prospective teacher, but it needs revision in the other certain parts.

While, the result of the lesson plan assessment which created by Pendidikan Bahasa Arab (PBA) students of Fakultas Tarbiyah dan Keguruan (FTK) UIN Sunan Ampel after the lesson plan presentation, peer assessment and intensive guidance with the lecturer and peer tutoring are seen on table 2.2. 
Table 2. The Result of Lesson Plan Assesment of 2013 Curriculum 2017 Revised Edition the last step after the lesson plan presentation, peer assessment, and guidance

\begin{tabular}{|c|c|c|l|c|c|}
\hline NO & Score & Predicate & Explanation & Total & $\%$ \\
\hline 1 & $\mathrm{~N}<70$ & $\mathrm{~A}$ & Need guidance & 3 & 10 \\
\hline 2 & $\begin{array}{c}71 \leq \mathrm{N} \leq \\
80\end{array}$ & $\mathrm{~B}$ & $\begin{array}{l}\text { Can be used as } \\
\text { the sample for } \\
\text { other prospective } \\
\text { students/teachers } \\
\text { by revising in } \\
\text { certain parts. }\end{array}$ & 5 & 16,6 \\
\hline 3 & $\mathrm{~N}>80$ & $\mathrm{C}$ & $\begin{array}{l}\text { Can be used as } \\
\text { the sample for } \\
\text { other prospective } \\
\text { students/teacher }\end{array}$ & 22 & 73,3 \\
\hline & & & Total & 30 & 100 \\
\hline
\end{tabular}

The finding on the table 2.2 show that $(10 \%)$ of the students still need a guidance in arranging and developing lesson plan, while the small portion $(16,6 \%)$ of the students, their lesson plan can be used as the reference and example to other students by revising certain parts and the most portion $(73,3 \%)$ of the students , their lesson plan got more than $80(\mathrm{~N}>80)$ score and it recommended to be used as the reference or example to other students. From the finding on table 2.2, it can be said that generally the lesson plan which created by the students of prospective Arabic teacher of PBA study program of FTK UIN Sunan Ampel can be used as the reference for other students/ prospective teacher even teacher in position.

According to the result of the lesson plan, assessment from the students of PBA FTK UIN Sunan Ampel can be said that generally, the competence of the students of prospective Arabic teachers in arranging and developing lesson plans was good. It supported by the portfolio- based learning model and it directly made the students active in the learning process. The students learned theoretically then practice it directly and produced a portfolio in form of the lesson plan.

Students' Problems faced by the students of the PBA study program of FTK UINSA in arranging and developing a lesson plan and the solution.

Table 3. The Arrangement and Development of Lesson Plan

\begin{tabular}{|c|c|c|c|}
\hline NO & $\begin{array}{l}\text { The arrangement of Lesson } \\
\text { Plan }\end{array}$ & $\mathbf{F}$ & $\%$ \\
\hline 1 & $\begin{array}{l}\text { Having difficulties in arranging } \\
\text { lesson plan }\end{array}$ & 5 & 16,7 \\
\hline 2 & $\begin{array}{l}\text { Having no difficulties in } \\
\text { arranging lesson plan }\end{array}$ & 25 & 83,3 \\
\hline & Total & 30 & 100 \\
\hline
\end{tabular}


Based on the results of the questionnaire on table 1.1, it found that $(16,7 \%)$ small portion students who faced problems in arranging and developing lesson Plan, while the $(83,3 \%)$ were not faced problems in arranging and developing lesson Plan.

According to the result on table 1.1, generally, it can be said most of the students of Arabic study program of Fakuktas Tarbiyah dan Keguruan Universitas Islan Negeri Sunan Ampel were professional in arranging and developing a lesson plan and an only small portion which faced obstacles in arranging lesson plan. One of the causes was the implementation of a portfolio- based learning model of the lesson plan that involves the students directly in arranging lesson plan.

The next finding was the students' competence of PBA FTK UIN Sunan Ampel in formulating the indicator pencapaian kompetensi (IPK). Based on Process Standard of Permendiknas No 41 2007, indikator pencapaian kompetensi (IPK) is the attitude to measure and observe for showing the achievement of certain basic competence that becomes the reference of study program achievement.

Table 4. Formulating the Indikator Pencapaian Kompetensi (IPK)

\begin{tabular}{|c|l|c|c|}
\hline NO & $\begin{array}{l}\text { Formulating the Indikator } \\
\text { Pencapaian Kompetensi } \\
\text { (IPK) }\end{array}$ & F & \% \\
\hline 1 & $\begin{array}{l}\text { Having difficulty in } \\
\text { formulating Indikator } \\
\text { Pencapaian Kompetensi } \\
\text { (IPK) }\end{array}$ & 5 & 16,7 \\
\hline 2 & $\begin{array}{l}\text { Having no difficulties in } \\
\text { formulating Indikator } \\
\text { Pencapaian Kompetensi } \\
\text { (IPK) }\end{array}$ & 25 & 83,3 \\
\hline Total & 30 & 100 \\
\hline
\end{tabular}

Based on the results of the finding on table 1.2, it showed that $(16,7 \%)$ students faced problems in formulating the Indikator Pencapaian Kompetensi (IPK). While mostly $(83,3 \%)$ students were not facing problems in formulating Indikator Pencapaian Kompetensi (IPK).

Guiding the students to be skilled in formulating the indikator pencapaian kompetensi (IPK) is by practicing through the portfolio learning model.

After arranging the indikator pencapaian kompetensi (IPK), the teacher should be formulated the objectives of learning. The objectives of learning are drawing the process and the result of the learning, it hopes can be achieved by the students appropriate with 
the Kompetensi Dasar (KD). In this case, the learning objectives are the learning objective which contains in the lesson plan of the 2013 Curriculum Kurikulum 2017 Revised Edition wherein formulating the learning objectives it must include PPK (Penguatan Pendidikan Karakter).

Table 5. The Formulation of Learning Objectives K'13 2017 Revised Edition

\begin{tabular}{|l|l|c|c|}
\hline NO & \multicolumn{1}{|c|}{$\begin{array}{c}\text { The Formulation of } \\
\text { Learning Objectives }\end{array}$} & F & $\%$ \\
\hline 1 & $\begin{array}{l}\text { Having difficulty in } \\
\text { formulating the learning } \\
\text { objectives K'13 2017 Revised } \\
\text { Edition }\end{array}$ & 5 & 16,7 \\
\hline 2 & $\begin{array}{l}\text { Having no difficulties in } \\
\text { formulating the learning } \\
\text { objectives K'13 2017 Revised } \\
\text { Edition }\end{array}$ & 25 & 83,3 \\
\hline & \multicolumn{1}{|c|}{ Total } & 30 & 100 \\
\hline
\end{tabular}

According to table 1.3 , it informed that $(16,7 \%)$ students having difficulties in formulating and developing the learning objective. While mostly $(83,3 \%)$ students were not having difficulties in formulating and developing the learning objectives.

As an effort to improve the students' competence of prospective Arabic teachers in formulating the appropriate learning objectives, the thing which done by the lecturer was giving some of the examples of the learning objectives formulation which appropriated with K'13 2017 Revised Edition and included the PPK.

After formulating the learning objectives, the next competence is how to selecting or determining the learning method. The learning method is one of the components which include in the lesson plan.

Table 6. Choosing the Learning Method

\begin{tabular}{|l|l|c|c|}
\hline NO & $\begin{array}{l}\text { Choosing the Learning } \\
\text { Method }\end{array}$ & F & \% \\
\hline 1 & $\begin{array}{l}\text { Having difficulties in } \\
\text { choosing the learning } \\
\text { method }\end{array}$ & 5 & 16,7 \\
\hline 2 & $\begin{array}{l}\text { Having no difficulties in } \\
\text { choosing the learning } \\
\text { method }\end{array}$ & 25 & 83,3 \\
\hline & Total & 30 & 100 \\
\hline
\end{tabular}


The finding on the table showed that $(16,7 \%)$ the small portion of the students who had problems in choosing the learning method. While mostly $(83,3 \%)$ students were not having problems in choosing the learning method.

Table 7. Choosing/ Operating the learning Media

\begin{tabular}{|c|c|c|c|}
\hline $\mathrm{NO}$ & $\begin{array}{c}\text { Pemilihan/Pengoperasionalan } \\
\text { Media Pembelajaran }\end{array}$ & $\mathrm{F}$ & $\%$ \\
\hline 1 & $\begin{array}{l}\text { Mengalami kesulitan dalam } \\
\text { memilih/mengoperasionalkan } \\
\text { media pembelajaran }\end{array}$ & 0 & 0 \\
\hline 2 & $\begin{array}{l}\text { Tidak Mengalami kesulitan } \\
\text { dalam } \\
\text { memilih/mengoperasionalkan } \\
\text { media pembelajaran }\end{array}$ & 30 & 100 \\
\hline & Jumlah & 30 & 100 \\
\hline
\end{tabular}

While in choosing and operating the learning media on table 1.5, it was found that there were no students in the Pendidikan Bahasa Arab (PBA) study program of Fakultas Tarbiyah dan Keguruan (FTK) UIN Sunan Ampel who having difficulties in choosing/operating the learning media. It means that all the students were able to choose/operate the learning media well. Moreover based on the result of observation the writer as the lecturer of Learning Media on Pendidikan Bahasa Arab (PBA) study program of Fakultas Tarbiyah dan Keguruan (FTK) UIN Sunan Ampel, the students were able to choose and use various manual, electronic, and modern (computer and internet) media in learning.

Table 8. Arranging the Learning media

\begin{tabular}{|c|c|c|c|}
\hline NO & $\begin{array}{c}\text { Arranging the Learning } \\
\text { media }\end{array}$ & F & $\%$ \\
\hline 1 & $\begin{array}{c}\text { Having difficulties in } \\
\text { arranging learning material }\end{array}$ & 5 & 16,7 \\
\hline 2 & $\begin{array}{c}\text { Having no difficulties in } \\
\text { arranging learning material }\end{array}$ & 25 & 83,3 \\
\hline & Total & 30 & 100 \\
\hline
\end{tabular}


Meanwhile, the students' competence in arranging and mastering the learning material on table 1.6 shown that only $(16,7 \%)$ students who faced the difficulties in arranging and mastering the learning materials in lesson plan, while mostly $(83,3 \%)$ students were not faced the difficulties in arranging and mastering the learning material in lesson plan.

The next finding was the students of prospective teacher competence in determining the kind/technique and the assessment form.

Table 9. Determining The Kind/Technique And The Assesment Form

\begin{tabular}{|c|c|c|c|}
\hline NO & $\begin{array}{c}\text { Determining the } \\
\text { Kind/Technique and the } \\
\text { Assesment Form }\end{array}$ & F & \% \\
\hline 1 & $\begin{array}{c}\text { Having difficulties in } \\
\text { determining the } \\
\text { kind/technique and the } \\
\text { assessment form }\end{array}$ & 5 & 16,7 \\
\hline 2 & $\begin{array}{c}\text { Having no difficulties in } \\
\text { determining the } \\
\text { kind/technique and the } \\
\text { assessment form }\end{array}$ & 25 & 83,3 \\
\hline & \begin{tabular}{c} 
Total \\
\hline
\end{tabular} & 30 & 100 \\
\hline
\end{tabular}

Based on the table 1.7 it known that only (16,7\%) small portion of Arabic students in Fakultas Tarbiyah dan Keguruan (FTK) UIN Sunan Ampel were had difficulties in determining the kind/technique and the assessment form, while mostly $(83,3 \%)$ students were not had the difficulties in determining the kind/technique and the assessment form.

Meanwhile, the students of prospective Arabic teacher' problems of Fakultas Tarbiyah dan Keguruan (FTK) UIN Sunan Ampel in arranging the lesson plan based on the interview with the lecturer were because the syllabus and RPS did not fully accommodate the learning planning material so that the students' understanding also not complete, added with the inappropriate lecturing model, thus in 2017/2018 until now the lecturer who lectured this course should be reviewed and redesigned the syllabus, RPS/SAP of the Curriculum Development and Learning Planning and also delivered it by innovative model and strategy for achieving the learning objectives maximally. 


\section{Conclusion}

According to the result of the discussion, it can be concluded that the Curriculum Development and Learning Planning Course by applying the portfolio learning model in the PBA study program of FTK Universitas Islam Negeri Sunan Ampel Surabaya can improve the professionalism of the Arabic students in arranging and developing the lesson plan. The improvement shown by the result of the lesson plan assessment which created by the students were mostly $(73,3 \%)$ students, their lesson plan got score $\mathrm{N}<80$ that meant their lesson plan can be used to other students of prospective/teacher. Meanwhile, the problems which was faced by the students of prospective Arabic teacher in Pendidikan Bahasa Arab (PBA)study program of FTK UIN Sunan Ampel in arranging and developing lesson plan were $(16,7 \%)$ students who faced the difficulties in formulating Indikator Pencapaian Kompetensi (IPK), developing the learning objectives, choosing the learning method, arranging the learning material and determining the technique and assessment form. The solution to the students who still had difficulties in arranging and developing a lesson plan is by intensive guidance with the lecturer, applying the peer tutoring learning strategy, and presenting the lesson plan which created by the students in front of the class by peer assessment using 2013 Curriculum 2017 Revised Edition as the effort to help the students to cover the problems in arranging lesson plan and improving their professionalism in arranging and developing the quality of lesson plan. Then for the maximal result, it hopes that the portfolio learning model should be variated with the study lesson model in each meeting, especially in arranging the lesson plan.

\section{References}

Ali, Muhammad. "Peningkatan Kemampuan Guru Dalam Menyusun Rencana Pelaksanaan Pembelajaran (RPP) Melalui Supervisi Akademik", Dalam Nusantara (Jurnal Ilmu Pengetahuan Sosial), Vol 3 Desember (2017).

Arman, Ali. "Upaya Peningkatan Kompetensi Guru Dalam Menyusun Rencana Pelaksanaan Pembelajaran Melalui Supervisi Akademik Kepala Sekolah Di Sman 1 Lembah Melintang Kabupaten Pasaman Barat", Dalam Jurnal Manajemen Pendidikan, Vol 1 No. 1 (2016).

Hadhari Nawawi. Metode Penelitian Bidang Sosial. Yogyakarta: Gajah Mada University Press, 1995.

Hamzah B. Uno. Perencanaan Pembelajaran,. Jakarta: PT. Bumi Aksara, 2016. 
Himmah, Hizmatul Ro'fat., Amrulloh, Afif Muhammad. Pengembangan Kurikulum Bahasa Arab Pesantren Mu'adalah (Studi Kasus Di Pondok Pesantren Al-Kausar Genteng-Banyuwangi), Dalam Jurnal Al-Bayan Vol. 9, No.2. 234-248 , (2017).

Ilyas, Alinis. "Dosen Bahasa Arab Dan Kompetensinya Dalam Mengaktualisasikan

Teknik Pembelajaran Interaktif", Dalam Jurnal Al Bayan Vol. 10, No. 1. 86-102 (2018).

Khaerani, Candra, Noriko. "PENINGKATAN KOMPETENSI GURU DALAM MENYUSUN RPP MELALUI KEGIATAN IHT (IN HOUSE TRAINING)", Dalam Jurnal Penelitian Tindakan Kelas, Vol 17 No 1 (2016).

Lampert, Magdalene, And Filippo Graziani. "Instructional Activities As A Tool For Teachers' And Teacher Educators' Learning." The Elementary School Journal 109.5: 491-509. (2009).

Lederman At.Al, The Preservice Microteaching And Science Teachers Instructional Decisions: A Qualitative Analysis. Jounal Of Research In Science Teaching 27

717-726. (1990).

Maryani, Ika. Bhakti, Putra Caraka. Strategi LPTK Dalam Pengembangan Kompetensi Pedagogik Calon Guru Dalam Jurnal Pendidikan Vol. 1 No. 2 (2006). 98-106.

Mendikbud. "Permendikbud No. 22 Tahun 2016 Tentang Standar Proses.” Jakarta, 2016.

Muhaimin. Paradigma Pendidikan Islam. Bandung: Remaja Rosda Karya, 2004.

Muspawi, Mohamad. " Profesionalitas Guru Dalam Menyusun Rencana Pelaksanaan Pembelajaran (Rpp) Pada Sekolah Dasar Negeri No. 76/Ix Desa Mendalo Darat Kec. Jaluko Kab. Muaro Jambi", Dalam Jurnal Penelitian Universitas Jambi: Seri Humaniora, Volume 17 No. 1 (2015).

Norma Izzati. "Meningkatkan Kemampuan Mahasiswa Dalam Menyusun RPP Melalui Penerapan Model Pembelajaran Berbasis Portofolio".” Jurnal Euclid, Jurnal Euclid, 4 No. 1 (2017): 659.

Nazuhi, Mukh. "Meningkatkan Kompetensi Guru Dalam Penyusunan Rpp Yang Baik Dan Benar Melalui Pendampingan Berbasis Mgmp Semester Satu Tahun 2015/2016 Di SMP Ngeri 16 Mataram", Dalam Jurnal Ilmiah IKIP Mataram, Volume 3 No. 1 (2016).

Prodi PBA FTK UINSA. "Struktur Kurikulum Pendidikan Bahasa Arab Fakutas Tarbiyah Dan Keguruan UIN Sunan Ampel Berbasis KKNI.” FTK UINSA, 2016.

Pringle, R. M. Dawson, K. And Adams, T. Technology, Science And Preservice Teachers: Creating A Culture Technoligy-Savvy Elementary Teachers. Action In Teacher Education, 24 (4), 46-52 (2003). 
Rachmadi, Denny. Peningkatan Kemampuan Guru Dalam Menyusun RPP Melalui Pelatihan Di SMA N 1 Karangrayung", Dalam Jurnal Profesi Keguruan, Volume 3 No. 1 (2017).

Rukayah, "Peningkatan Kompetensi Guru Dalam Perencanaan Pembelajaran Tematik Melalui Supervisi Kelompok Pendekatan Kolaboratif", Dalam Kelola Jurnal Manajemen Pendidikan, Volume: 5, No. 1, Januari-Juni 2018.

Sa'bani, Faizuz . "Peningkatan Kompetensi Guru Dalam Menyusun RPP Melalui Kegiatan Pelatihan Pada Mts Muhammadiyah Wonosari", Dalam Jurnal Pendidikan Madrasah, Volume 2, Nomor 1, Mei 2017.

Sangad. "Meningkatkan Kemampuan Guru Dalam Penyusunan Rencana Pelaksanaan Pembelajaran (Rpp) Yang Berkarakter Melalui Supervisi Akademik", Dalam Jurnal Ilmiah Edukasi, Vol 4 No 2 (2016).

Srimulyani, Mamik. "Meningkatkan Kompetensi Guru Dalam Menyusun Rpp/Rplbk Dengan Pendekatan Saintifik/Pendekatan Bk Melalui Metode Workshop Di Sekolah Binaan Kota Malang Tahun 2017", Dalam Prosiding SENASGABUD (Seminar Nasional Lembaga Kebudayaan), Edisi 1 (2017).

Subramaniyam, Kartigheyan. Creating A Microteaching Evaluation Form: The Needed Evaluation Criteria. Education 126 (2), 666-677. (2006 ).

Team Borang PBA FTK UINSA. "Borang Prodi PBA FTK UINSA 2016.” FTK UINSA, N.D.

Team Dosen PBA. "Silabus Mata Kuliah Pengembangan Kurikulum Dan Perencanaan Pembelajaran Program Studi PBA Pada FTK UIN Sunan Ampel Surabaya.” Prodi PBA UINSA, 2018.

Team Dosen PPL 1 PBA UINSA. Tidak Diberikannya Mata Kuliah Perencanaan Pembelajaran (I'dad Al-Ta'lim) Adalah Karena Terlewatkan (Kealpaan) Pihak Prodi. Pada Akhirnya Sebagai Solusi Dimasukkan Ke Dalam Mata Kuliah PPL 1 (Include) Pada Semester Tersebut (N.D.).

Team Pengembang SMAN I Tenjo. "Upaya Peningkatan Kompetensi Guru Dalam Menyusun Silabus Dan Rpp Melalui Supervisi Akademik Secara Berkelanjutan Di SMAN I Tenjo Bogor", Dalam Laporan Penelitian Tindakan Sekolah. (Bogor: Dinas Pendidikan Kabupaten Bogor, 2010).

Umi Hanifah. "Laporan Penelitian 2017 "Inovasi Pembelajaran Pada PPL-1 Prodi PBA FTK UIN Sunan Ampel: Upaya Meningkatkan Profesionalisme Calon Guru." Surabaya: LPPM - UIN Sunan Ampel, 2017.

Yuliati, Lia. Pengembangan Model Pembelajaran Untuk Meningkatkan Kemampuan Mengajar Calon Guru Fisika Dalam JIP: Jurnal Ilmu Pendidikan Vol 14 No. 1 (2007). 
Yuniar, Marwa, Atikah. "Al-'Alaqah Baina Al-Kafaah Al-Mihniyyah Li Mu'allim Wa Raghbati Al-Talamidz Fi Ta'allum Al-Lughah Al-'Arabiyyah Bi Maharah Qiro'ah Al-Nash Al-'Arabiyyah Bi Al-Madrasah Al-'Aliyyah Al-Muhajirin Muwas Rawas Sumatra Al-Junubiyyah", Dalam Jurnal Al-Bayan: Jurnal Jurusan Pendidikan Bahasa Arab, Vol 10 No. 1 (2018). 